Article received on 19 September 2013

Article accepted on 30 September 2013

UDC: $785: 316.774$

785.6:785(436.1)"2013"

\author{
Marija Maglov* \\ University of Arts in Belgrade \\ Faculty of Music \\ Department of Musicology
}

\title{
THE VIENNA NEW YEAR'S CONCERT AS A MEDIA PHENOMENON ${ }^{1}$
}

\begin{abstract}
This paper is aimed at drawing attention to the problem of the media representation of artistic music, through the case study of the television broadcast of the New Year's Concert in Vienna. The text contains a brief historic summary of the concert and its broadcast within the European television network, Eurovision. Using this year's broadcast (2013) as an example, certain aspects are marked that potentially represent a starting point for further interpretations of the New Year's Concert and, generally, the relationship between artistic music and media.
\end{abstract}

Key words: the New Year's Concert in Vienna, Eurovision, public broadcaster, media representation of class, media

\section{Introduction}

For many people, watching the broadcast of the Vienna New Year's Concert each $1^{\text {st }}$ January is part of a festive ritual. Even those who do not watch

\footnotetext{
* Author contact information: marijamaglov@gmail.com

1 This paper was written under the mentorship of Professor Vesna Mikić, PhD, within the course Theory and Practice of Media in Musicology, academic year 2012/13, study programme Musicology-Master, at the Department of Musicology at the Faculty of Music in Belgrade.
} 
the broadcast know at least something about the concert: for example, that the repertoire consists mostly of pieces written by the Strauss family and that almost every year, The Blue Danube waltz by Johann Strauss the Younger and the Radetzky March by Johann Strauss the Elder are performed as encores. Thanks to the medium of television, this concert, which cannot be attended by everybody, has nevertheless found its way into the lives of people from various countries, most of all European, and the idea about it forms certain meanings among different European nations, whose members have separate cultural, social and class positions. Therefore, this concert is a media phenomenon that deserves particular attention.

Generally speaking, the issue of the media presence and representation of artistic music is very interesting, yet it seems that it has not drawn the attention of media theoreticians. I draw this conclusion from the consulted literature, which includes mostly books related to the medium of television, but also general overviews of key notions and concepts in media studies. However, music overall is not neglected in media and television studies. Popular music is one of the first 'lessons' about media theory, which includes the analysis of views of the Frankfurt School theoreticians, and regarding the television studies, dealing with the emergence of Music Television (MTV) is practically unavoidable and problematized because of, among other things, the revolutionary role of a song video in the music industry. ${ }^{2}$ As John Hartley wrote, the common denominator of media studies and popular culture (including music) was their (lower) position compared to the traditional disciplines advocated by the dominant academic public (the author speaks particularly about philosophy), i.e. compared to the dominant high culture. ${ }^{3}$ Thus, it seems that popular culture and the media are necessarily connected. Popular culture is certainly the dominant content of the media, while the traditional arts do not appear to be 'alluring' enough for the media, and so they are present either in specialized programmes (such as e.g. the ARTE and MEZZO channels, or RTS Digital in Serbia) or on special occasions (e.g. on a Day of Mourning). In Hartley's opinion, it is the low media frequency of a particular content that makes that content valuable. Thus, he states that symphonic music can retain its 'serious' status precisely due to its low media frequency, while popular music, due to high media frequency, cannot escape the status of a commercial, 'unworthy' product. ${ }^{4}$

\footnotetext{
2 The need to present the makers of popular music on television too, instead of just on radio as was previously customary, expedited the changes in the music industry. Perhaps the best illustration of that is the title of the song "Video Killed the Radio Star" by The Buggles.

3 John Hartley, Television Truths, Blackwell Publishing Ltd, 2008, 3-4.

${ }^{4}$ John Hartley, op. cit., 56.
} 
Apart from what has been said about the media position of artistic music, one should also take into account whether the media are American or European. American culture is considered a synonym for popular culture, which is therefore the most frequently represented in the American media, which are private property. On the other hand, Europe relies on the model of the 'public broadcaster', which in its beginnings had clearly defined its goals and mission to promote, among other things, the European cultural heritage, which includes precisely the works of traditional art. ${ }^{5}$ Since the Vienna New Year's Concert is distributed through Eurovision, a European television network that mainly covers the public broadcasters of most European countries, the particulars of the public broadcasters will be presented more thoroughly in the context of dealing with Eurovision.

Besides, we shall give a brief historical summary of the Vienna New Year's Concert. Since numerous authors in television studies have developed various approaches and concepts, which are, by their content, mostly related to popular culture, we shall not indulge in a detailed analysis of the concert broadcast. Instead, we shall point out certain aspects, such as the problem of the media representation of class in the New Year's Concert broadcasts.

\section{The New Year's Concert in Vienna - a brief history}

The first of the many New Year's Concerts in Vienna was held on $31^{\text {st }}$ December 1939 in the Golden Hall of the Viennese Musikverein, with Clemens Krauss conducting, and the programme consisted entirely of compositions by Johann Strauss the Younger. ${ }^{6}$ The Vienna Philharmonic did not always foster the tradition of performing music by the Strauss family. Namely, although the orchestra during the $19^{\text {th }}$ century held several concerts with Johann Strauss, who conducted his own music, it was Krauss who initiated the tradition of concerts consisting only of music by the Strauss family, in performances within the Salzburg festival (1929-1933). ${ }^{7}$ Curiously enough, the interest in Strauss's music, "the most Viennese music ever written", ${ }^{8}$ emerged in the interwar pe-

${ }^{5}$ Cf. "Public Service Broadcasting", in: Critical dictionary of film and television theory (Roberta F. Pearson and Philip Simpson, eds.), Routledge, London - New York, 2001, 489490; "Public Service Broadcasting", in: Bernadette Casey, Neil Casey, Ben Calvert, Liam French and Justin Lewis, Television Studies. The Key Concepts, Routledge, London - New York, 2002, 135-137.

${ }^{6}$ The first concert's programme can be seen at: http://en.wikipedia.org/wiki/Vienna_New_ Year\%27s_Concert, accessed on 23 $3^{\text {rd }}$ January 2013.

7 http://www.wienerphilharmoniker.at/index.php?set_language $=$ en $\&$ cccpage $=$ newyearscon cert history, accessed on $23^{\text {rd }}$ January 2013.

8 Ibid. 
riod, after the collapse of the Austro-Hungarian monarchy. At that time, the idea of the belle époque, "the golden age", was still vividly remembered by the Viennese. It was the period of memories of the splendour and sumptuousness of the city, balls, waltzes, of times when newspapers contained more reports about culture than politics, as Stefan Zweig wrote in his memoirs. ${ }^{9}$ By the time the first New Year's Concert was held, Vienna was far away from its glorious past, having become a province of Nazi Germany with the annexation of Austria the year before. Under such circumstances, organizing a New Year's Concert awakened a prominent note of nostalgia, and precisely this image of Vienna as the city of culture would be strongly emphasized later on, when the invention of televised broadcasts would make it possible to use the concert increasingly for the promotion of Austrian culture and heritage, i.e. cultural and touristic marketing. However, regarding the concerts held during the Second World War, one should keep in mind that all the revenues went to the National-Socialist treasury ("Kriegswinterhilfswerk"), and that the conductor Krauss was forbidden to perform publicly for two years after the War. During that time, the concert was conducted by Josef Krips, and then Krauss again until 1954. Since 1941, the concert has been organized regularly every $1^{\text {st January. }}{ }^{10}$

After Krauss's retirement, the New Year's Concert was conducted by Willy Boskovsky, the concertmaster of Vienna Philharmonic, for the next 25 years. During that period, in 1959, the regular television broadcasts of the concert turned into a tradition. They are realized by the Austrian public broadcaster ÖRF and distributed by Eurovision.

In 1980, the orchestra members invited the American conductor Lorin Maazel, who would conduct the New Year's Concerts until 1986. Since 1980, adorning the hall with flowers donated by the Italian city of San Remo has become another tradition. After 1986 it became customary to have different conductors from all over the world every year. ${ }^{11}$ The reason for the decision to have a new world-renowned conductor every year might have been the marketing, because the concert drew increasing media attention (the number of countries broadcast-

\footnotetext{
9 Štefan Cvajg, Jučerašnji svet [Stefan Zweig, Die Welt von gestern], trans. Aleksandar Tišma, Službeni glasnik, Belgrade, 2009

10 Apart from the concert on $1^{\text {st }}$ January, whose televised broadcast is the subject of this paper, the Vienna Philharmonic organizes two more concerts, on the $30^{\text {th }}$ and $31^{\text {st }}$ December, with the same programme.

11 The first among these conductors was Herbert von Karajan, and the list of conductors who have performed at the New Year's Concert in the subsequent years can be seen at: http://www.wienerphilharmoniker.at/index.php?set_language $=$ en\&cccpage $=$ newyearsconce rt_history, accessed on $23^{\text {rd }}$ January 2013.
} 
ing the concert is greater by the year). Since 1979, audio and video recordings of the concert have become commercially available. ${ }^{12}$

Regarding the repertoire of the concerts, music by the Strauss family members still occupies the better part of them. Apart from their waltzes, polkas, marches, operetta overtures and other compositions, frequent programme entries are pieces by other Viennese composers, such as Josef Hellmesberger, Joseph Lanner, Otto Nikolai, Franz von Suppé and others. On anniversaries of great composers of artistic music, some of their works are included too. Thus, for example, 200 years from birth of Joseph Haydn was honoured in 2009, by the performance of the fourth movement of his "Farewell Symphony", and this year's concert was marked by the $200^{\text {th }}$ anniversaries of Verdi's and Wagner's births. However, the most iconic segments of the concerts are the encores, three of them altogether. The first one is a fast polka of the conductor's choice, the second is The Blue Danube waltz, and the third is the Radetzky March. The custom of performing the latter two compositions as encores was established only a few years after the concerts' inception. The waltz was first included in the regular concert programme in 1945, and the Radetzky March was first performed in 1946 as an encore. However, only since 1958 have both compositions been regularly performed as encores, a custom skipped in just two instances: in 1967 the waltz was performed in the regular programme, and in 2005 conductor Lorin Maazel did not perform the Radetzky March as a mark of respect for the victims of the Indian Ocean tsunami in the previous year. ${ }^{13}$

\section{Television broadcast of the New Year's Concert. The Eurovision}

The television broadcast of the New Year's Concert is a live telecast of the concert's programme, which used to begin at 12.15 PM until 1990. Since then, the concert has had two parts and begins an hour earlier. During the intermission, a short film made by the ÖRF is shown, usually promoting Austrian nature and culture. Besides, sometimes short "television postcards" are inserted into the main programme, mostly with similar content. Ballet numbers have also become a usual part of the concert, either pre-recorded or (since 1987) broadcast

12 http://en.wikipedia.org/wiki/Vienna_New_Year\%27s_Concert, accessed on 23 ${ }^{\text {rd }}$ January 2013. Thus PGP-RTS in 1988, with the Deutsche Grammophon license, released the LP recording of the New Year's Concert in 1987 (240028 STEREO SOKOJ), while the compact disc (440060) and the audio cassette (540099 STEREO SOKOJ) with the same content were released in 1991. Information from the database of PGP-RTS.

$13 \mathrm{http}: / /$ en.wikipedia.org/wiki/Vienna_New_Year\%27s_Concert, accessed on $23^{\text {rd }}$ January 2013. 
live from Schönbrunn Palace. ${ }^{14}$ Regarding the television broadcast, it is worth noting that it has always been realized using the most advanced technology, from the introduction of the PAL standard for colour television, analogue stereo sound, to contemporary digital television of high definition - HDTV and multichannel digital audio - Dolby Digital 5.1. Since 2010, the concert has also been broadcast as a live stream over the Internet.

As previously said, the concert's television broadcast has been organized since 1959. This concert is one of several events broadcast by Eurovision, the television network of the European Broadcasting Union (EBU). ${ }^{15}$ Besides the New Year's Concert, the most famous music event organized and broadcast by Eurovision is the Eurovision Song Contest, a pop music competition. It is typical for European television to dedicate equal importance to popular and artistic music, i.e. the respective concert broadcasts, in Eurovision's "programme schedule". This is nothing out of the ordinary, keeping in mind the basic idea of every public broadcaster in Europe, hence Eurovision too, which is "the representative of public service broadcasting in Europe". ${ }^{16}$

The concept of public service broadcasting and changes that have occurred in that concept during the $20^{\text {th }}$ century are a complex issue whose details will be left aside for now. ${ }^{17}$ It is important to present some basic features of a public broadcaster which can be recognized in the contemporary concept of Eurovision too, as well as perceived from the official position of the European Broadcasting Union: this network exists "to promote and develop a number of public interest purposes, based on values such as human rights, freedom of expression, democracy, cultural diversity ...) and to help its Members to serve the interests of the general public in the best possible manner". ${ }^{18}$ In short, a public broadcaster can be defined as a system aimed at working in the public interest instead of a particular commercial or political interest. ${ }^{19}$ It is marked by a balance of tastes to be satisfied, given that it reaches out to the broad audience. ${ }^{20}$ We should keep in

\footnotetext{
14 http://de.wikipedia.org/wiki/Neujahrskonzert_der_Wiener_Philharmoniker, accessed on $23^{\text {rd }}$ January 2013.

15 The list of member states can be seen at: http://sr.wikipedia.org/sr-el/Списак_чланица Европске_радиодифузне_уније, accessed on 23 $3^{\text {rd }}$ January 2013.

$16 \mathrm{http} / /$ www3.ebu.ch/files/live/sites/ebu/files/About/EBU\%20Code\%20of\%20Ethics.pdf, accessed on $23^{\text {rd }}$ January 2013.

17 More on that in: Critical dictionary of film and television theory, op. cit.; Television Studies. The Key Concepts, op. cit.

${ }_{18} \mathrm{http} / /$ www3.ebu.ch/files/live/sites/ebu/files/About/EBU\%20Code\%20of\%20Ethics.pdf

${ }^{19} \mathrm{Cf}$. Critical dictionary of film and television theory, op. cit.

${ }^{20}$ Ričard Paterson, "Televizija", in: Uvod u studije medija (Adam Brigs i Pol Kobli, ur. [Richard Paterson, "Television" in: The media: an introduction (Adam Briggs and Paul Cobley, eds.)], trans. Irena Šentevska, Clio, Belgrade, 2005.
} 
mind that public broadcasters are often regulated by state administration; hence they are not completely independent of all kinds of politics. The difference from commercial broadcasters is that public broadcasters try to ensure freedom of expression for different voices, although most of the time their programme will be strongly coloured by the ideology of the dominant policy, especially in times of crisis. As far as the programme ideas of public broadcasters are concerned, they are based on the opinions of John Reith, the first Director-General of the BBC. Reith advocated broadcasting content which would "shape and 'promote' public taste," ${ }^{21}$ and which included theatre plays, artistic music, poetry and so on. Obviously, Reith's ideas were defined by his notion of general culture as the culture of the upper middle class and by a personal hostility towards popular culture. Although conceptual changes in public service broadcasting gradually led to a departure from Reith's ideas, with the inclusion of more elements of entertainment and popular culture, his ideas can still be recognized in the public broadcasters' obligation to present an educational content based precisely on the traditional arts and their canonical works. Besides, the prominent place taken by artistic music in the concept of Eurovision also speaks of a strong awareness that this music is an important part of European tradition.

The values that Eurovision also endeavours to support, and for which purpose it was presumably established in 1950, are the ideas of the European solidarity. Namely, the united media could "... spread ideas and beliefs, conveying to the audience messages about identity and unity within a diverse set of cultures". ${ }^{22}$ The New Year's Concert has obviously proven to be an appropriate content, promoting the ideas of peace, humanity and "love among nations". This is also underlined by the views of the Viennese Philharmonic Orchestra, which was appointed a Goodwill Ambassador of the World Health Organization in 2005. What stands out among the views is that the orchestra "has made it its mission to communicate the humanitarian message of music into the daily lives and consciousness of its listeners", as well as the musicians' endeavour to implement the motto of Beethoven's Missa solemnis - "From the heart, to the heart". ${ }^{23}$

With such a notion of the New Year's Concert, it seems that this event is really not a problematic spot in the television programme or culture generally. The impression is reinforced by an interesting fact about the attitude of the Soviet authorities towards the New Year's Concert broadcasts during the Cold War. Namely, although the major part of the media content broadcast in the

${ }^{21}$ Cf. Critical dictionary of film and television theory, op. cit.

${ }_{22}$ Cf. Ričard Paterson, op. cit.

${ }^{23}$ http://www.wienerphilharmoniker.at, accessed on $23^{\text {rd }}$ January 2013. 
West European countries was strictly controlled and often officially banned in the countries behind the 'Iron Curtain', the New Year's Concert was one of the rare events whose live broadcast was allowed. ${ }^{24}$

Despite the New Year's Concert appearing to be an area of 'innocence' in the media and culture, which seemingly, at the height of general optimism at the beginning of a new year, should eliminate all wondering about class, racial, gender, social, economic issues of modern society and provide a moment of 'reconciliation', the question inevitably arises: Is that really so?

As Hartley says, "[a] certain critical suspicion of media manipulation is always healthy, because the motives of those who exploit TV commercially and politically are not entirely pure". ${ }^{25}$ On the other hand, John Fiske emphasizes that, to understand television in this way, we need to see it and its programmes as potentials of meaning rather than as commodities. ${ }^{26}$ An additional reason for such an approach is that television is a very powerful medium and while watching it, "[we] are not consuming a product but using the imaginative resources of story, song, sight, and sound - some of the most powerful tools known to humanity - to think about identity, relationship, and community, in real time and space" ${ }^{27}$ We should nevertheless keep in mind that the experience of watching television is always personal and strongly shaped by social and cultural determinants, such as gender, age-group, family, class, nation, and ethnicity. ${ }^{28}$ Therefore, television and consumers are involved in an interactive relationship, and given the many foregoing disparities among the general audience, it is clear that the ways in which television functions in a society are extremely diverse, and no theoretical apparatus can fully provide an adequate insight into all of them. ${ }^{29}$ However, I shall try to outline certain aspects which might be interesting for further interpretations.

For example, the analysis of the concert and its programme give rise to further considerations about the problem of the popularization of artistic music, which has been particularly interesting since the introduction of the mass elec-

${ }^{24}$ http://it.wikipedia.org/wiki/Concerto_di_Capodanno_di_Vienna, accessed on $23^{\text {rd }}$ January 2013.

${ }^{25}$ John Hartley, op. cit., 4.

${ }^{26}$ John Fiske, Television culture: popular pleasures and politics, Routledge, London - New York, 1987, 13.

27 John Hartley, op. cit., 6.

${ }^{28}$ Ibid., 5.

${ }^{29}$ Cf. John Fiske, op. cit., 2. 
tronic media in the $20^{\text {th }}$ century. Although this would require complex research and interpretation, the results could pinpoint the works from the canonical repertoire of artistic music which are particularly agreeable to the general audience. These issues could be oriented towards searching for the answer in the very structure of certain works, or else in the analysis of a discourse in which the awareness about particular works is formed that precisely those compositions are able to 'enlighten' and represent the achievements of supreme art in the best possible way.

It would also be interesting to analyse the myth of artistic music as one which 'transcends boundaries,' making it suitable for occasions such as the New Year, when the idea of a possible future without conflicts is celebrated. But does artistic music really bring reconciliation every single time? Or is it, on the contrary, is it the area which defines the difference? ${ }^{30}$

Actually, where it concerns the New Year's Concert, it is interesting to think in what measure this concert underlines certain differences - for example, class distinctions? The New Year's Concert is an exclusive event, and the opportunity to attend such a manifestation is a matter of prestige, or possibly luck. The latter case refers to a commercial venture by the concert's management, which organizes an annual lottery in which the applicants, provided their names are drawn, can buy tickets for the concert at greatly reduced prices. However, for most viewers, attending the concert is beyond their reach. The tickets are exceedingly expensive, and some seats in the hall belong to certain families, who have the right to hand down the use of them from generation to generation. The television image leaves no doubt about exclusivity: the magnificence of the hall adorned with gilt and floral arrangements, and the audience in formal attire, among whom one can often see the faces of the political or aristocratic elite.

What kind of attitude towards the concert and the music performed at it can be developed by the inhabitants of some other 'world' who watch the broadcast? Issues of class and the images of a class in the media, though ignored in media studies for a while, are very explicitly imposed in this case. Questions arise about one's own class position when facing the representation of the representation of a class displayed on the screen, or its values. As Joanna Lacey underscores, the analysis of class is not just the analysis of scenes of the working class; it is the analysis of the image of members of the middle class and upper classes; it should deal with examining the ways in which spectators perceive various images of a class. How do we understand what it means to be a member

${ }^{30}$ Cf. e.g. Pierre Bourdieu's concept of "cultural capital". Pierre Bourdieu, Distinction. A Social Critique of the Judgment of Taste, Harvard University Press, 1984. 
of the working class, the middle, or upper class? Is it rooted in experience, or in mediated ways of seeing and getting to know the Other class? ${ }^{31}$

This issue is further complicated by the fact that the concert, in one way or another, has nevertheless become a part of the tradition of many families from various classes, all thanks to broadcasting. Television has introduced a kind of 'democratization,' where something that was meant for 'the chosen' minority became available to everybody. It is as if the live telecast of the concert dispels the event's aura of exclusivity, making it accessible to all. But is that really so, or is it just an illusion, a strategy by a society which aspires to blur the boundaries between the classes?

A special segment in the concert broadcast is a short film during the intermission. This year (2013) the subject was "Honeymoon". It has already been mentioned that the pre-recorded material telecast during the concert most often has a very clear purpose: to present the travel destinations of Austria. The very fact that this marketing action powerfully promotes the culture of a country for political and commercial purposes, the action which includes all the above mentioned connotations of Vienna as the city of culture, apparently is not so guileless. However, this year's film "Honeymoon" is a particularly interesting case. Namely, it is a story about a couple who spend their honeymoon travelling through various regions of Lower Austria, and their adventures are accompanied with recorded scenes from appropriate picturesque communities. The couple, however, soon turn out to be not just any couple enjoying romance and nature, but an upper class couple who can afford an expensive vacation with champagne and a diamond necklace as the husband's gift to the wife. Obviously, a very clear class positioning, and hence the clear message as to who the target group of this film is. The use of diamonds in the content of popular culture was analysed by Fiske, who states that the meaning of jewellery in the code of gender is clear. "Jewels are the coins by which the female-as-patriarchal-commodity is bought, and wearing them is the sign both of her possession by a man, and of his economic and social status." ${ }^{2} 2$ Diamonds in this context are used as a gift that every man (the ideal tourist in Austria) should, naturally, provide his wife with, whereby "the economics of patriarchy are the same for all classes". ${ }^{33}$ Let alone the fact that diamonds are not accessible to all classes. Obviously, here Fiske distinguishes the meaning of patriarchy as the dominant meaning. So, this

31 Cf. Džoana Lejsi, "Društvena klasa. Identifikovanje klasnih karakteristika u medijskim tekstovima" [Joanna Lacey, "Social class. Identifying characteristics of class in media texts"], in: Uvod u studije medija, op. cit., 527.

32 John Fiske, op. cit., 13.

${ }^{33}$ Ibid. 
is highlighted in the promotional film, the soundtrack of which (a collage of various compositions, from Mozart to Piazzolla) is played by members of different groups of the Vienna Philharmonic. Is patriarchal domination present in this orchestra as well? It is enough to watch a video recording of the concert and count the female members: there is but a handful of women. Out of 135 active musicians in the orchestra members list, only eight are women. ${ }^{34}$ Judging by its structure and the overall programme of the concert broadcast, including the said film, it seems that the orchestra is advocating - subtly but undeniably - the ideology of patriarchal capitalism. Fiske spots the indicators of this ideology in the content of popular culture, but it is obvious that the media image of artistic music would also provide interesting material for a similar analysis.

In this paper I have tried to emphasize the importance of the media representation of artistic music. Although many music lovers, musicians and all those who feel that artistic music is not represented enough in the media need to follow the rare media contents dedicated to artistic music with acclaim, benevolence and delight, this should not weaken the awareness that each media content, including this one, needs to be observed critically. It is precisely the media position of artistic music that can direct our attention to a multitude of questions about society in which this music is the vehicle of certain meanings and the indicator of different power relations.

Translated by Goran Kapetanović

$34 \mathrm{http}: / /$ www.wienerphilharmoniker.at/index.php? set_language $=$ en\&ccpage $=$ musicians, accessed on $23^{\text {rd }}$ January 2013. 
